\title{
The Disconnect Between Green Marketing And Green Consumption: A Case Study Of Kisii County, Kenya
}

\author{
Fred Ongisa
}

\begin{abstract}
The purpose of this paper is to analyse the link or lack of it between green marketing and green consumerism in Kenya. The paper examines the concepts of green marketing, green purchasing and green consumerism in order to identify the disconnect between the theory and practice. The study found that consumers pay little attention to eco-labelling, eco-advertising. To this end, product characteristics such as recyclability and easy disposal are rarely considered when making purchases. There are few studies on the role both consumers and firms Kenya can play towards sustainable development. It is the intention of this paper to inform a debate on Kenya's place towards global green economy.
\end{abstract}

Keywords: green purchasing; green consumption; green marketing; sustainable development Paper type: Conceptual paper

\section{Introduction}

There has been increasing global pressure for governments, businesses and societies to concern themselves with the state of environment (Brown, 2008; Manaktola and Jauhari, 2007). This has been due to the environmental problems such as global warming, ozone depletion and pollution (Leonidou et al., 2010; Svensson and Wagner, 2012). The United Nations Conference on Sustainable Development (UNCSD), also known as Rio 2012, hosted by Brazil in Rio de Janeiro from 13 to 22 June 2012 recognised that there should be fundamental changes in the way societies consume and produce in order to achieve global sustainable development. Although many firms in the country claim to practise sustainable development, like many Kenyan towns, Kisii Town suffers from dangerously high levels of air pollution, poor quality of water, high levels of garbage disposal and rapidly diminishing space. The key question in this study is: Is there a chasm between green marketing and green consumption in Kenya?

In this context, green purchasing has a strategic contribution to sustainable development and more specifically the environment (Green et al., 1995; Lamming et al., 1996). Although this global phenomenon is recent, the potential of purchasing to contribute to sustainable development was mentioned as early as 1975 by Taylor (Murray, 1999a). Terms such as sustainable procurement (SP), environmentally preferable purchasing (EPP) and green purchasing (GP), green marketing have been used in different literature. Environmental Preferable Purchasing is defined as buying, "products or services that have a lesser or reduced effect on human health and the environment when compared with competing products or services that serve the same purpose" (EPA, 2000). GP is also defined as an environmentally conscious purchasing initiative that tries to ensure that purchased products or materials meet environmental objectives set by the purchasing entity/ or individual, such as reducing the sources of wastages, promoting recycling, reuse, resource reduction, and substitution of materials (Carter et al., 1998; Min and Galle, 2001; Zsidisin and Siferd, 2001). GP ensures that purchasing organizations or consumers consider the issue of sustainability in the purchasing of inputs, in addition to the traditional purchasing criteria of cost, quality, and delivery (Jimenez and Lorente, 2001; Kannan et al., 2008; Lambert and Cooper, 2000). According to Hamner (2006) the seven basic GP activities are;

(1) Product content requirements. Buyers specify that purchased products must have desirable green attributes such as recycled or reusable items.

(2) Product content restrictions. Buyers specify that purchased products must not contain environmentally undesirable attributes such as lead, CFCs, plastic foam in packaging materials.

(3) Product content labelling or disclosure. Buyers require disclosure of the environmental or safety attributes the contents of the purchased product. Such disclosure can be done using green seals and indicators of relative environmental impact such as scientific certification system offered by various commercial organizations.

(4) Supplier questionnaires. Buyers send questionnaires to suppliers asking them to provide information about their environmental aspects, activities and/or management systems.

(5) Supplier environmental management systems. Buyers require suppliers to develop and maintain an EMS. However, the buyer does not require the supplier to certify the system.

(6) Supplier certification. Buyers require suppliers to have an EMS that is certified as fully compliant with one of the recognized international standards such as the British Standard 7750, ISO 14001 from the ISO, and the European Union Eco-Management and Audit Scheme. 
(7) Supplier compliance auditing. Buyers audit suppliers to determine their level of compliance with environmental requirements.

Previous research identified numerous factors that influence firms to adopt green initiatives. For instance, Rao (2006) stated that consumer pressure and expected business benefits are the most influential factors affecting GP. Forman and Jorgensen (2004) affirmed that regulation, consumer pressure, social responsibility (SR) and expected business benefits have significant effects on GP. Min and Galle (2001) argued that regulation and expected business benefits are the most significant drivers. However household consumption accounts for more than 60 percent of all environmental impacts and 80 percent of this impact occur during end use (UNEP, 2010). Due to this, current attention to consumers' participation in sustainable consumption is growing (Park and Ha, 2011; The World Business Council for Sustainable Development, 2008). Despite the importance of GP in combating environmental problems and generating economic benefits, available evidence shows that GP is still not widely adopted in Kenya partly because of consumer apathy towards the initiative. Unfortunately little research has been done on the area of consumer perception of green purchasing in Kenya. This paper tries to initiate that discussion.

\section{Green purchasing}

The area of green purchasing continues to excite several researchers both in developed and developing countries. However, in the developed countries, this attention has shifted towards consumer environmentalism (Juwaheer et al 2012; Mintel, 2006). "Green consumers' demonstrate an interest in product's characteristics such as recyclability and chemical content, preferring consumption of products that are organic, energy efficient or have biodegradable packaging (Leonidou et al., 2010;). The industry for green products in the USA is estimated at over \$250 billion (Papadopoulos et al. 2010; Gupta and Ogden, 2009).

\section{Green marketing}

Green marketing incorporates a range of activities including product modification, changes to the production process, packaging changes and advertising. It means promoting products with environmental characteristics such as recyclable, ozone friendly, eco-friendly (Zhu et al., 2007a; Rao, 2006; Min and Galle, 2001; Mourad and Ahmed, 2012). Many companies worldwide are adapting a green marketing strategy to secure themselves against legislative regulations, respond to green consumer demands and to compete with other green offerings (Lee, 2010; Delmas and Toffel, 2004 and Hoffman, 2001)), or to change their whole business culture (Carter and Jennings, 2002; Polonsky and Rosenberger, 2001). Nevertheless, the ultimate goal for green marketing is to create two bottom lines; the first is for profit and the second for social responsibility (Mourad and Ahmed, 2012).

According to Lee (2008) green marketing has undergone different stages since 1980s. The first decade marked the first stage that was characterized by how environmental problems could be solved. During the second stage in 1990s, there was wide consumer cynicism that slowed down green marketing momentum (Peattie and Crane, 2005). According to the writers, there were five marketing practices which led to the failure of green marketing during this period. They are:

(1) Green spinning. Using public relations to deny or discredit the public's criticisms against the company's practices. This is mostly by industries in oil, chemicals and pharmaceuticals.

(2) Green selling. Taking an opportunistic approach by adding some green claims to existing products with the intention of increasing sales.

(3) Green harvesting. Becoming enthusiastic about the environment only when going green could result in cost savings (energy and material input inefficiencies, package reductions, etc.).

(4) Enviropreneur marketing. Developing innovative green products to market without really understanding what the consumers actually want.

(5) Compliance marketing. Companies use simple compliance to environmental legislation to promote themselves as green firms.

Gradually green marketing evolved into ethical consumerism (Uusitalo and Oksanen, 2004)

Ethical consumerism refers to buyer behaviour that reflects a concern with the problems that arise from unethical and unjust trades, such as child and low-paid labour, infringement of human rights, animal testing, labour union suppressions, inequalities in trading relations with the Third World and pollution of the environment(McEachern, M.G. and McClean, 2002; Uusitalo and Oksanen, 2004). Since the demand for green products is uneven across different marketplaces

(Peattie, 1992), it seems that Kenya is at the second stage of green marketing evolution which was characterized by consumer cynicism and indifference towards waste disposal. 
The Disconnect Between Green Marketing And Green Consumption: A Case Study Of Kisii County,

\section{Green consumption}

Many of the green marketing studies have focused on consumer attitudes, behaviours' impact on green purchasing and the gender of green consumers. These variables are generally divided as either sociodemographic or psychographic (Diamantopoulos et al., 2003; Leonidou and Leonidou, 2011; Luzio et al., 2013). For example, Juwaheer et al. (2012) analysed the impact of green marketing strategies on consumer purchasing patterns. Their study found that there was a strong positive correlation between marketing strategies and consumer purchasing patterns of green products. Consumers are also depicted as playing a major role in environmental sustainability since they can exert considerable pressures and demand goals of sustainability or environmental performance from businesses (Perry and Singh, 2002; El Tayeb et al., 2010). Several studies show consumer attitudes and behaviour as complex and vital in understanding green purchasing. According to Cheah and Phau (2011) Consumers with favourable attitudes towards environmentally friendly products are more likely to purchase environmentally friendly products. They demonstrated that consumers with eco-literacy, interpersonal influence and value orientation have strong correlations with attitudes towards environmentally friendly products. Green product purchasers exhibited significantly higher levels of cognitive attitude, affective attitude, social norm, personal norm, and recycling intention (Park and Ha, 2012). However some researchers are sceptical of the concept of 'green consumers'. Bonini et al. (2008) highlighted that 53 percent of consumers in Brazil, Canada, China, France, Germany, India, the UK, and the US are ideally concerned about environmental issues but are not practically and actively protecting the environment. In addition, Pickett-Baker and Ozaki (2008) argued that people who are environmentally conscious do not necessarily purchase green products and services. GP is varied and context specific- consumers could buy conventional products but still exhibit environmentally friendly practices such as appropriate recycling or disposal (Luzio et al., 2013; Laroche et al., 2001; Wheale and Hinton, 2007). Unfortunately, the Kenyan consumer has not exhibited environmentally friendly practices such as environmentally preferable purchasing or appropriate disposal. The consumer might not choose green products because of other considerations such as cost, quality and loyalty.

\section{Conclusion}

Many organizations especially multinationals in Kenya have embraced the concept of green economy as advocated by The United Nations Conference on Sustainable Development (UNCSD). However, not enough has been done to sensitize the consumers. Kenyan consumer seems apathetic about green products. Since majority of Kenyans are literate, efforts towards green consumption by stakeholders would be easily accepted.

\section{References}

[1]. Brown, D. (2008), "It is good to be green: environmentally friendly credentials are influencing business outsourcing decisions", Strategic Outsourcing: An International Journal, Vol. 1 No. 1, pp. 87-95.

[2]. Bonini, S.M.J., Hintz, G. and Mendonca, L.T. (2008), “Addressing consumer concerns about climate change”, McKinsey Quarterly, available at: www.mckinseyquarterly.com/ Strategy/Strategic_Thinking/Addressing_consumer_concerns_about_climate_change_ 2115 (accessed 25 August 2013).

[3]. Carter, C.R., Ellram, L.M. and Ready, K.J. (1998), "Environmental purchasing: benchmarking our German counterparts", International Journal of Purchasing \& Materials Management, Vol. 34 No. 4, pp. 28-38.

[4]. Carter, C.R. and Jennings, M.M. (2002), "Logistics social responsibility: an integrative framework", Journal of Business Logistics, Vol. 23 No. 1, pp. 145-180.

[5]. Cheah, I and Phau, I. (2011), "Attitudes towards environmentally friendly products: the influence of ecoliteracy, interpersonal influence and value orientation", Marketing Intelligence and Planning, Vol.29 No.5 pp452-472.

[6]. Delmas, M. and Toffel, M. (2004), "Stakeholders and environmental management practices: an institutional framework", Business Strategy and the Environment, Vol. 13 No. 4, pp. 209-22.

[7]. Diamantopoulos, A., Schlegelmilch, B.B., Sinkovics, R.R. and Bohlen, G.M. (2003), "Can socio-demographics still play a role in profiling green consumers? A review of the evidence and an empirical investigation”, Journal of Business Research, Vol. 56 No. 6 , pp. $465-480$

[8]. El Tayeb, T., Zailani, S. and Jayaraman, K. (2010), “ The examination of the drivers for green purchasing adoption among EMS14001 certified companies in Malaysia”, Journal of Manufacturing Technology Management. Vol.21 No. 2 pp $206-225$.

[9]. Environmental Protection Agency (EPA) (2000), "State and local government pioneers: how state and local governments are implementing environmentally preferable purchasing

[10]. practices", available at: www.epa.gov/oppt/epp (accessed 21 August 2013).

[11]. Gupta, S. and Ogden, D.T. (2009), "To buy or not to buy? A social dilemma perspective on green buying", Journal of Consumer Marketing, Vol. 26 No. 6, pp. 376-91.

[12]. Hoffman, A.J. (2001), "Linking organizational and field-level analysis: the diffusion of corporate environmental practice", Organization and Environment, Vol. 14, pp. 133-156.

[13]. Juwaheer, T., Pudaruth, S. and Noyaux, M. (2012), “ Analyzing the impact of green marketing strategies on consumer purchasing patterns in Mauritius", World Journal of Entrepreneurship Management and Sustainable Development. Vol.8 No.1 pp. 36-59.

[14]. Lambert, D.M. and Cooper, M.C. (2000), "Issues in supply chain management", Industrial Marketing Management, Vol. 29 No. 1, pp. 65-83.

[15]. Lamming, R. and Hampson, J. (1996), "The environment as a supply chain management issue", British Journal of Management, Vol. 7, pp. S45-S62, (special issue).

[16]. Laroche, M., Bergeron, J. and Barbaro-Forleo, G. (2001), "Targeting consumers who are willing to pay more for environmentally friendly products", Journal of Consumer Marketing, Vol. 18 No. 6, pp. 503-20. 
[17]. Lee, K. (2008), “Opportunities for green marketing: young consumers” Marketing Intelligence and Planning, Vol.26 No.6 pp573 586

[18]. Leonidou, L.C., Leonidou, C.N. and Kvasova, O. (2010), “Antecedents and outcomes of consumer environmentally friendly attitudes and behaviour", Journal of Marketing Management, Vol. 26 Nos 13/14, pp. 1319-1344.

[19]. Leonidou, L.C., Leonidou, C.N., Palihawadana, D. and Hultman, M. (2011), "Evaluating the green advertising practices of international firms: a trend analysis", International Marketing Review, Vol. 28 No. 1, pp. 6-33.

[20]. Luzio, J. and Lemke, F. (2013), "Exploring green consumers' product demands and consumption processes: the case of Portuguese green consumers" European Business Review, Vol.25 No. 3 pp 281-300.

[21]. McEachern, M.G. and McClean, P. (2002), "Organic purchasing motivations and attitudes: are they ethical?", International Journal of Consumer Studies, Vol. 26 No. 2, pp. 85-92.

[22]. Manaktola, K. and Jauhari, V. (2007), "Exploring consumer attitude and behavior towards green practices in the lodging industry in India", International Journal of Contemporary Hospitality Management, Vol. 19 No. 5, pp. 364-77.

[23]. Min, H. and Galle, W.P. (2001), "Green purchasing practices of US firms", International Journal of Operations \& Production Management, Vol. 21 No. 9, p. 1222.

[24]. Mintel (2006), "Green living”, US Marketing Research Report, London. Mourad, M. and Ahmed, Y. (2012), "Perception of green brand in an emerging innovative market”, European Journal of Innovation Management, Vol. 15 No. 4 pp 514-537

[25]. Murray, J.G. (1999a), "Local government demands more from purchasing", European Journal of Purchasing and Supply Management, Vol. 5 No. 1, pp. 33-42.

[26]. Papadopoulos, I., Karagouni, G., Trigkas, M. and Platogianni, E. (2010), "Green marketing: the case of Greece in certified and sustainably managed timber products”, Euro Med Journal of Business, Vol. 5 No. 2, pp. 166-90.

[27]. Park, J. and Ha, S. (2012),'Understanding pro-environmental behavior: a comparison of sustainable consumers and apathetic consumers", International Journal of Retail and Distribution Management, Vol. 40, No. 5 pp 388-403.

[28]. Peattie, K. (1992), Green Marketing, Pitman Publishing, London.

[29]. Peattie, K. (2001), "Golden goose or wild goose? The hunt for the green consumer", Business Strategy and the Environment, Vol. 10 No. 4, pp. 187-99.

[30]. Peattie, K. and Crane, A. (2005), “Green marketing: legend, myth, farce or prophesy?”, Qualitative Market Research, Vol. 8 No. 4, pp. 357-70.

[31]. Pickett-Baker, J. and Ozaki, R. (2008), "Pro-environmental products: marketing influence on consumer purchase decision", Journal of Consumer Marketing, Vol. 25 No. 5, pp. 281-93.

[32]. Polonsky, M.J. and Rosenberger, P.J. III (2001), "Reevaluating green marketing: a strategic approach", Business Horizons, September/October, pp. 21-30.

[33]. Rao, P. (2006), "Greening of suppliers/in-bound logistics in the South East Asian context", in Sarkis, J. (Ed.), Greening the Supply Chain, Chapter 11, Springer, London, pp. 189-204.

[34]. Svensson, G. and Wagner, B. (2012), "Business sustainability and E-footprints on Earths life and ecosystems: generic models", European Business Review, Vol. 24 No. 6, pp. 543-552.

[35]. Uusitalo, O. and Oksanen, R. (2004), "Ethical consumerism: a view from Finland", International Journal of Consumer studies, Vol. 28 No. 3, pp. 214-21.

[36]. Welford, R. (2000), Hijacking Environmentalism, Earthscan, London.

[37]. Wheale, P. and Hinton, D. (2007), "Ethical consumers in search of markets", Business Strategy and the Environment, Vol. 16 No. 4, pp. 302-315.

[38]. World Summit on Sustainable Development (2002), Plan of Implementation of the World Summit on ustainable Development, United Nations, New York, NY.

[39]. Zhu, Q., Sarkis, J. and Lai, K.-H. (2007a), "Initiatives and outcomes of green supply chain management implementation by Chinese manufacturers", Journal of Environmental Management, Vol. 85 No. 1, pp. 179-89.

[40]. Zhu, Q., Sarkis, J. and Lai, K. (2008), "Confirmation of a measurement model for green supply

[41]. chain management practices implementation", International Journal of Production Economics, Vol. 111 No. 2, pp. 261-73.

[42]. Zsidisin, G.A. and Siferd, S.P. (2001), "Environmental purchasing: a framework for theory development", European Journal of Purchasing and Supply Management, Vol. 7 No. 1, pp. 61-73. 